HOW

Volume 28, Number 3, pages 154 - 172

https://doi.org/10.19183/how.28.3.683

HOW

\title{
Local Identity Studies of Gender Diversity and Sexual Orientation in ELT
}

\author{
Estudios Locales de Identidad sobre la Diversidad de Género \\ y la Orientación Sexual en la Enseñanza de Inglés \\ como Lengua Extranjera
}

\section{Harold Castañeda-Peña ${ }^{1}$}

\begin{abstract}
While it is true that identity studies on the intersection between gender and sexual orientations with language teaching and learning are not new in the local context, the systematization of these studies as a body of knowledge is scarce. This article presents, first of all, a systematization of reference frameworks for this type of studies in historical perspective. Secondly, it presents a reflection on the collective achievements in this field of study. Finally, the article concludes with a brief reflection on potential actions at the research and pedagogical levels.
\end{abstract}

Keywords: ELT, identity, gender, sexual orientation

\section{Resumen}

Si bien es cierto que los estudios identitarios sobre la intersección entre el género y las orientaciones sexuales con la enseñanza y el aprendizaje de lenguas no son nuevos en el contexto local, la sistematización de estos estudios como un cuerpo de conocimiento es escasa. Este artículo presenta, en primer lugar, una sistematización de los marcos de referencia para este tipo de estudios en perspectiva histórica. En segundo lugar, presenta una reflexión sobre los logros colectivos en este campo

He teaches in the ELT Education Emphasis at Doctorado Interinstitucional en Educación and in the Master Program of Education and Technology at Universidad Distrital Francisco José de Caldas. He is interested in identity, gender, information literacy and videogaming related to language learning and teacher education. He was ASOCOPI President.

hacastanedap@udistrital.edu.co

ORCID ID: https://orcid.org/0000-0002-6828-8712

Received: July 21st, 2021. Accepted: July 30th, 2021.

This article is licensed under a Creative Commons Attribution-Non-Commercial-No-Derivatives 4.0 International License. License Deed can be consulted at https://creativecommons.org/licenses/by-nc-nd/4.0. 
de estudio. Finalmente, el artículo culmina con una breve reflexión sobre potenciales acciones a nivel investigativo y pedagógico.

Palabras clave: ELT, identidad, género, orientación sexual

\section{Introduction}

This special issue celebrates HOW journal's 25 years of numbered issues. This is an extraordinary moment to trace back what has been achieved by the Colombian Association of Teachers of English -ASOCOPI-- and by Colombian scholarly work around specific English language teaching (ELT) topics and trends. In that line of celebration, the annual ASOCOPI congress and to a certain extent the journal HOW have become the forum wherein the interphase between gender and ELT has been examined. This year, the world also celebrates the $52^{\text {nd }}$ anniversary of the well-known Stonewall riots in New York (USA) that signaled new avenues for understanding non-normative sexualities and genders. "While there is little doubt that the Stonewall riots changed the trajectory of the gay rights movement, it is less clear as to why they gained a worldwide significance" (D'Emilio, 2002, in Varga, Beck, \& Thornton, 2019, p. 35). Questioning what has happened locally and what stories have been told are important. This is useful to locate within a broader social panorama research studies which discover, also locally, the connections between gender and ELT.

This paper then briefly describes theoretical frameworks that have been used to account for identity issues related to educational contexts of language teaching and learning. By way of reflection, this is an approach to studies carried out in my line of research that needs to be complemented with other local studies not referenced in this article and that will be considered in a later study. The article ends with the introduction of ideas for a broad research program and potential pedagogical actions. The resulting curricular implications of research about this particular interrelation (e.g., gender and ELT) are likely to generate more questions than answers.

\section{Gender, the LGBTIQ+ Context and Language Learning}

Data taken from the 2020 Human Rights Bulletin by Colombia Diversa (colombiadiversa. org), the organization that fights for LGBTIQ+ rights in the country, demonstrate that over the last year homicides and feminicides have been committed (around 75); furthermore, threats and intimidations of different forms affected around 24 LGBTIQ+ people. Then, police violence against this community was registered (around 27 cases), and gender misrepresentation and errors in published news about LGTBIQ+ people have resulted in stigmatization. This is the first time that Colombia Diversa has introduced a "geostatistical analysis of data showing specific contextual factors that increase the risk of violence against LGBT people". 
Although this statistical information is fundamental to understand what is happening, thinking about educational contexts is still necessary, in particular about those in which foreign languages are taught. It seems also necessary to understand gender discrimination and discrimination based on sexual orientation occurring in language classrooms.

Most research papers on gender and language learning begin by making conceptual clarifications as to the difference between sex and gender within the framework of language and its uses. In the white and Western feminist line, there are classic works that begin with a reflection on the relationship between gender and language (Sunderland, 2006; Talbot, 2010; Coates, 2011; Eckert \& McConnell-Ginet, 2013) explaining this from perspectives of dominance (language supporting patriarchal societies), deficit (women being less sophisticated in terms of language use), and difference (stereotyped uses of language by women and men). There are also works that go beyond this discussion and analyze gender and language from a political and discursive perspective adding ideas of sexuality, such as the works of Butler (2004, 2011, 2015), Cameron (2006), and Cameron and Kulick (2006). Finally, there are works that focus on the intersection of gender and the learning of foreign languages such as German, French, and English. These works include classic feminist authors such as Litosseliti (2006) and Sunderland (1992, 1998, 2000, 2004).

\section{Framing (Gender \& LGBTIQ+) Identity(ies) Studies}

By way of balance, it is possible to argue that a good part of the above cited works is based on a heterosexist gender perspective that denounces the subordination of women. Nevertheless, the broad background of these works can be found in trends of thought that studies identities comprehensively and that discusses distinguishable epistemological frameworks. For the study of identities and, by extension, of gender and LGBTIQ+ identities, three broad frameworks can be considered: (1) modern, (2) postmodern, and (3) the geopolitics of knowledge.

\section{The Modern Framework}

The modern framework for the study of identities essentially seeks explanations based on the establishment of patterns. This perspective calls for the stabilization and generalization of stages that add up one by one to form an identity. Three approaches stand out within this framework. They are the evolutionary approach (Hall, 1904), the phenomenological approach (Taylor, 1992), and the cultural approach (Berger \& Luckman, 2008). The evolutionary approach is based on the recapitulation theory that recognizes humanity as universal and inseparable from its natural condition. As a result, identity goes through formative steps that every human being goes through. The phenomenological approach understands identity as a phenomenon that is generalizable to all human beings. Although 
identity is based on personal experience, this experience is natural, essential, and inevitable. The cultural approach understands identity manifestations from the relationship between the self and morality. Identity in this framework is defined by shared horizons of meaning that determines what is valuable and good. In other words, identity codes are universally shared. Within this perspective, a series of gender roles are socially differentiated and considered immovable. It also crosses the lines of the medicalized and biological discourse. This is the reason for the identification of oppositions comparing male and female brains, skills or abilities, and also those that are constructed under the idea that women are better at languages compared to men.

\section{The Postmodern Framework}

The postmodern framework of identity consists of four main approaches: performative, discursive, technological, and genealogical. The performative approach is based representatively on the scholarly and reflexive work of Butler (2015) and Preciado (2008). To perform is basically to present identity as a dramatic act, like a scene in a play. Goffman (1959, p. 40) argues that "while in the presence of others, the individual infuses his activity with signs which dramatically highlight and portray confirmatory facts that might otherwise remain unapparent or obscure." This basically allows affirming that identity as performativity is critical and socially situated. This presents a great challenge to the school system and to the foreign language classroom: a number of performances may be desirable in specific contexts. Hence, the school regulates the way bodies perform their multiple identities. The presentation of the self is often subjected to the gaze of the other, which is why language teachers and students with non-normative genders and sexualities become undesirable in the regulated school system. This corresponds to the idea of gender stabilization that Butler (2015) explores by stating that the "disciplinary production of gender effects a false stabilization of gender in the interest of the heterosexual construction and regulation of sexuality within the reproductive domain" (p. 172). This leads to the understanding of (gender) identity from a discursive perspective: "if a true gender is a fantasy instituted and inscribed in the surface of bodies, then it seems that gender can be neither true nor false, but are only produced as the truth effects of a discourse of primary and stable identity" (Butler, 2015, p. 174).

From the discursive approach, which favors studies related to the gender identities of foreign language teachers and students with non-normative sexualities, Hall's (2011) contribution is pivotal. Identity has become a catch-all concept that corresponds to modernity. Therefore, Hall (2011) proposes to consider rather the processes of identification. According to the author, "the discursive approach sees identification as a construction, a process never completed - always 'in process'. It is not determined in the sense that it can always be 'won' or 'lost', sustained or abandoned" (Hall, 2011, p. 2). The author uses the metaphor of suture. A suture is a stich or a row of stiches that join the edges of a wound. Similarly, identity can 
be understood as a suture that holds two edges together: the subject and the structure. Thus, the suture is not something permanent but temporary, giving rise to the multiple existence of sutures that unravel over time. If this metaphor is accepted, then identity is evanescent, temporary and not fixed or determined. Hall (2011) argues that he uses the term identity,

To refer to the meeting point, the point of suture, between on the one hand the discourses and practices which attempt to 'interpellate', speak to us or hail us into place as the social subjects of particular discourses, and on the other hand, the processes which produce subjectivities, which construct us as subjects which can be 'spoken'. Identities are thus points of temporary attachment to the subject positions which discursive practices construct for us. (Hall, 2011, p. 6)

Discursive practices generate discursive formations (Foucault, 2002). Genealogy allows discovering how these discursive formations have been configured over time and have tended to stabilize. This is why, faced with the study of gender and LGBTIQ+ identities of foreign language students and teachers, it is important to recognize how discourses have been appropriated in school contexts. This is achieved by examining educational policies in general, and in particular, sex and gender education policies. The latter have been defended by the conservative extreme right in our country, which has prevented progress in sex education to embrace gender diversity. Just as Hall (2011) uses the metaphor of the suture, Haraway (1985) uses the metaphor of the chimera to reflect on the evanescent nature of identity. A chimera, in the Greek mythological tradition, is constructed by a lion's head, the body of a goat, and the tail of a snake. It is an identity conundrum that resembles a fracture of identity itself, i.e., identity is not monolithic. The chimera in the framework of technology is a cyborg. The cyborg transgresses the Cartesian identity image that individuals are mind and body. In this sense, the cyborg dilutes identity binarism that totalizes discursive images, for example, gender and sexual orientations. The cyborg technological condition that fuses the human and the machine makes identity something chimerical with an unmeasurable sense of hybridity.

In addition, considering queer theories is important and meaningful for all these proposals for queer gender studies relating sexual orientations as well. One example lies in the emergence of global queer theological theories that have been challenging the canonical reading of the scriptures of various religions (Cheng, 2013; Shore-Goss, 2019). All these approaches constitute different frameworks for the study of identities in general, and in

158 particular of gender and LGBTIQ+ identities. However, despite the anti-essentialist character of the approaches of the postmodern framework, the framework of the geopolitics of knowledge puts in dispute all these approaches that disagree from a perspective of historicity.

\section{The Geopolitics of Knowledge}

In analyzing how the knowledge that circulates in the Western world has been constituted, Grosfoguel (2013) determined the supremacy of a type of knowledge historically instituted 
despite the existence, survival, or annihilation of others. This is what he calls epistemicide. In light of gender and LGBTIQ+, it is worth asking: where do the contemporary understandings of gender, sex, sexual orientation, gay, lesbian, transgender, etc., come from? Perhaps we speak of modern understandings that hinder other types of understandings that have not achieved, for many reasons, a state of universalizing circulation and appropriation. In a nutshell, this is what gives rise to reflections of the decolonial perspective whose origins cannot be explained, for reasons of space, in this brief presentation of interpretative frameworks of identities. However, within this anti-colonial stance, there are possibilities to speak of the coloniality of power (Quijano, 2007), of being (Maldonado-Torres, 2007), of knowledge (Lander, 2000) and, of course, of the coloniality of gender (Lugones, 2008). It is important to remember that interculturality (Walsh, 2007) is also part of this position.

Regarding gender, within the decolonial framework there has also been colonialism; issues related to modern gender and LGBTIQ+ identities have gone through great struggles against subjection. Part of that history has been constructed by decolonial feminisms within which there are different positions and strands, especially in Latin America.

\section{Some Latin-American Decolonial Feminist Views about Gender}

I present below other views on gender issues that could be considered a body of knowledge constituting a decolonial turn on future gender studies about social and cultural contexts and, with emphasis, about educational and foreign language learning contexts.

Segato (2010) introduces the idea of gender genocide. This is due to the fact that there is a supremacy of its conceptualization mainly from white and middle-class perspectives. This would also apply critically to the representativeness of LGBTIQ+ identities. Segato's reflection claims, from the decolonial turn, an epistemological status for the category of gender that is not rooted in Eurocentrism or Anglocentrism. This implies thinking about a multifaceted re-existence of gender. Therefore, the task for applied linguistics to foreign language teaching lies in digging into the history of its own analytical categories, such as gender, in order to conduct inter-epistemic dialogues.

In relation to gender-related epistemological absences, Marcos (2014) puts forward a broad agenda for decolonial feminisms. She includes not only her concern for the marginalization of indigenous groups but also for the climatic and environmental affectation that the action of neoliberal political programs has brought as a consequence. In a lively way, Marcos (2014) points to contemporary processes of dispossession. What happens in contemporary foreign language classrooms is a continuous dispossession of gender. That is, bodies are hollowed out of their gender in favor of the technical teaching of language for communication. This means that in actual pedagogical practice, transmissive foreign language 
learning environments are created that forget social identity traits such as gender and sexual orientations. One can learn from indigenous feminisms that life itself is embodied. Thinking of foreign language teaching as an embodied process is something that the discipline should consider carefully.

For Lugones (2008), “categorial naming constructs what it names" (Lugones, 2008, p. 81). Therefore, in thinking about gender, one is constructing specific identities from specific frameworks of understanding. This is why Lugones (2008) calls for thinking about categories such as patriarchy, heterosexuality, and biological dimorphism within contemporary social relations and their roles in the colonial domination of gender. This questions the homogenization and emptiness of some intersections co-opted by modernity that perpetuate the masculine, white and Christian and, in that sense, the hierarchical and patriarchal. Finally, Mendoza (2016) contributes to the understanding of diverse decolonial feminisms where there is the Latin American perspective with various trends and streams as well as feminisms from other latitudes that fight against contemporary colonialisms such as the English and French.

\section{Knowledge Constructed within the Research Interest of (Gender \& LGBTIQ+) Identity Studies and ELT}

In accepting the invitation to write about my achievements in this field of study, I considered it important to say that this is not a personal accomplishment. Therefore, in this section, where the learning gained is storied, there is an interweaving of not only my personal research but also of the finished research studies that I have advised at the undergraduate and graduate levels. This means that I will move from the personal "I" to the collective "we" using an essayistic style. In this way, the efforts of my students and colleagues who have engaged in the dynamics of trying to comprehend the intersection between gender-diverse identities and the learning and teaching of foreign languages are acknowledged.

The epistemological frameworks presented in the previous sections have oriented, over time, the research work presented in Figures 1 and 2 below. Special reference is made to the postmodern frameworks of identity and in recent years to the decolonial perspective.

160 The learning about the intersection between gender/LGBTIQ+ identities and the context of foreign language learning and teaching are relevant from a local perspective.

A general characterization of the research work conducted over the past two decades shows a strong concern with representations of gender/LGBTIQ+ identities. Gender representations show the heteronormative tension that opposes the masculine to the feminine. For example, textbooks and materials used for teaching seem to be constructed from that discursive dichotomy. This means that genders are represented in traditional 

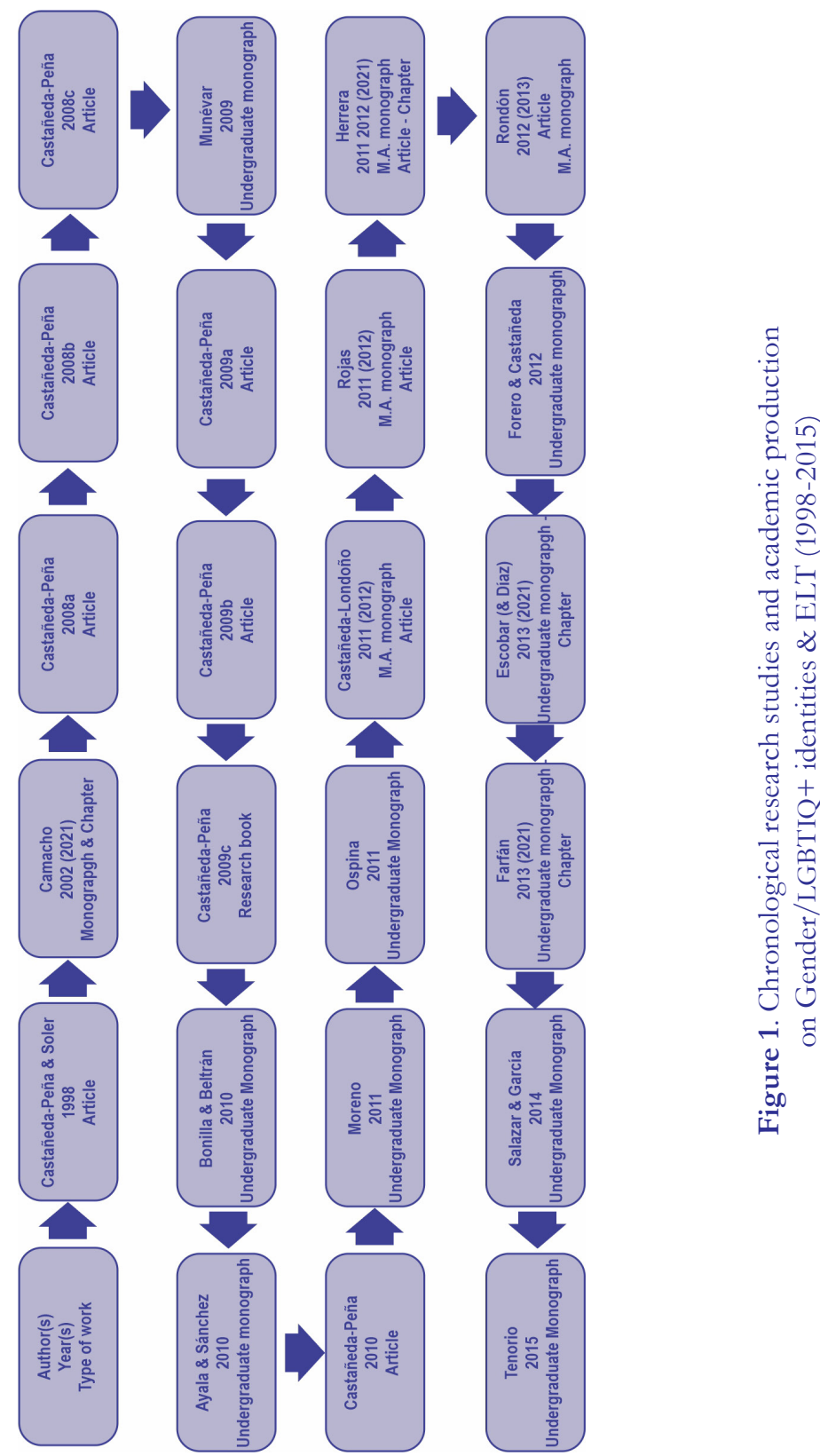


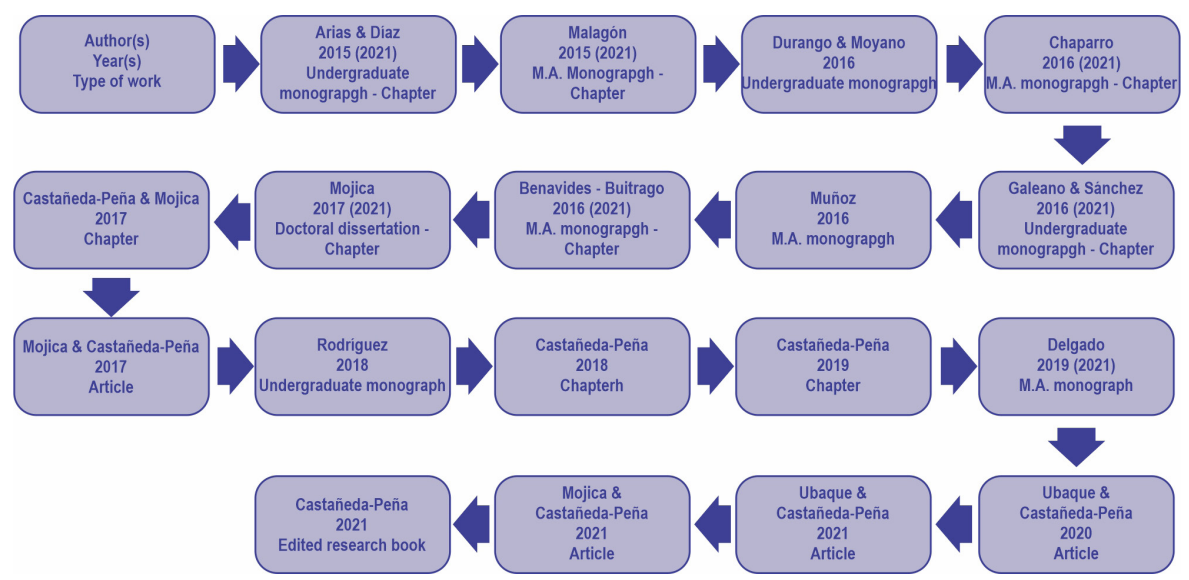

Figure 2. Chronological research studies and academic production on Gender/LGBTIQ+ identities \& ELT (2015-2021)

ways perpetuating traditional roles for both men and women. This heteronormative vision conveys an ideology that is harmful to language teachers and students who do not see themselves as identified or represented in the heterosexual school discourse. However, there are traces of rebellion against this heteronormative matrix and there are teaching materials that challenge the binary representation. This opens an important research space where the invitation is to move from investigating representations to investigating what is done with such representations in the language classroom. That is to say, when faced with a gender identity representation, both teachers and students of languages can assume it critically or can resist it in multiple ways.

Representations of LGBTIQ+ identities are less recurrent in foreign language teaching materials; however, they already exist. This can be a positive development. As important as

162 the inclusion of other identities related to diverse sexual orientations is, so is being cautious about it. That inclusion may correspond to universal movements about sexual education with which Colombia's educational policy has aligned. That alignment can impact the thematic curriculum of foreign language programs. Including issues of gender diversity with a universalizing perspective may cause identity itself to be co-opted by modernity. This is an important critique to keep in mind as the identity experience is not necessarily the same for all gender-diverse subjects. Therefore, one can politically and correctly begin to accept 
diverse subjects without necessarily understanding their life experiences. Consequently, we can be dealing with the construction of tolerated subjects but co-opted identities.

The ideas presented in classroom materials also translate well to the didactic designs of foreign language classes and the interactions that those designs promote. In the classroom contexts investigated, we can thoroughly demonstrate how an activity designed by the teacher can, probably unintentionally, propose a context of confrontation of the sexes from a heteronormative viewpoint. A classic example is class competitions in which women and men race against each other. Another example is the debates used to defend grammatically and communicatively ideas around a topic. What sometimes goes unnoticed are the ideologies imposed on students via forcing them to defend or oppose specific topics. It is within these activity designs that the classroom environment can be most unhealthy in relation to nonnormative genders and sexualities. This can happen in two ways. First, this is when a topic on gender or sex-gender diversity is made explicit in the language class in order to develop reading, writing, speaking or listening activities. That is, the ideologies communicated may be disrespectful of that diversity. The point here is to further examine what both teachers and students do with what is expressed in the classroom interaction. Second, the topic of the class is not necessarily geared to address gender issues, but in the interaction heterosexist ideologies explicitly emerge. This is another moment of apprenticeship that we still need to document further in order to guide the initial education of foreign language teachers or their continuing education.

Consequently, what we have learned is that examining the interface between gender diversity and language learning goes far beyond thinking about what is masculine and what is feminine and their interrelationships. We have learned that we need other epistemological frameworks that allow us to understand not only the masculine and the feminine but also gender diversity and the multiplicity of sexual orientations. At the beginning, we thought that these discursively constructed identities could be apprehended by looking at them from discourses of multiplicity, thinking that moving from the singular to the plural was simply necessary. That is, we argued the need to think not about masculinity but about masculinities. Thinking not about femininity but femininities also became necessary. However, this framework of thought retained a binary perspective that was also important to overcome. This led us to think that these analytical categories of gender diversity were co-opted by a colonial-modern mission. The fundamental task ahead was to decolonize the very epistemology that had guided us in our research work.

This leads us to think not only about the contexts investigated but also about the methodologies used for this purpose. Regarding the contexts, it is clear at this point that language learning cannot be reduced to the intentional pedagogical actions carried out in the language classroom. Language learning experiences do not simply happen in the language classroom; rather, they go much further and remain inked on the skin and are carried in 
the body over time. It is this corporeality of gender diversity that manifests itself in both public and private contexts where limits are blurred. Understanding this corporeality makes us step out of the bubble of gender and sexual diversity to try to understand them in an intersectional way. This means that gender diversity and sexual orientation do not operate in isolation. This reality manifests itself in an intersectional way, not as a sum of parts or identity features but as an unimaginable raveling of possibilities and potentialities. Therefore, we could assume intersectionality as a potentiality. Intersectionality, as coined by Crenshaw (1989), operates as a framework of analysis originally used to bring the intersection between "sex" and race out of marginalization. Over time this notion of intersectionality has evolved and other types of intersections have been investigated. Thus, what we perceive is that just as the boundaries of contexts have been blurred, the same should have happened with contemporary analytical categories. This makes us think that being disruptive conceptually and methodologically about hierarchies and oppositions within the knowledge generated in identity studies is necessary. This disruption is paramount to understand differently the intersection of the identities of gender diversity and sexual orientations in the field of foreign language learning and teaching.

In relation to the methodological aspect, we have seen that Latin American feminist positions challenge traditional forms of knowledge. This coincides with the decolonial position that questions the method itself. In particular, and based on a discursive and performative understanding of gender, we have mainly used critical and narrative methodologies. However, in the spirit of continuing to learn, questioning the method is also essential. There is a tendency to queer the method that is based primarily on a careful examination of how methodologies to study race and methodologies to study gender fall into the trap of the heterosexist matrix. Another argument arises from the eagerness of national policies when forced to respond to sexual diversity and that have ended up establishing homonormativity (Sabsay, 2012, 2016), ignoring a more faithful subjective sense of diversity. The intention of this self-criticism is to avoid falling into a colonial logic of both the method and the interpretative framework. Within this debate, it is worthwhile asking ourselves what is the way forward to avoid falling into such a methodological prison. We believe that the first thing to do is to disrupt the knowledge we claim to possess and try to unlearn. A second possible

164 step is to try to find innovative ways to get out of the extractivist logic to obtain data. If the intention is to co-construct knowledge, traditional methods such as interviews, observation, and surveys, among others, deserve to have a multi-significance. The purpose is not to give voice to others or to obtain information from others but rather to learn with others. This intention implies another type of relationality among those who participate in a research process. The question that remains unanswered is how to challenge extractivist logics and how to reach relationships that untie hierarchies. In the same line of thought, both narrative and autobiographical studies need to examine whether the knowledge generated is located 
in modern logics. For example, Pazargadi, (2019, p. 142) affirms that "empathetic witnessing $[\ldots]$ forms a key element in applying the narrative approach because it uses life stories to increase awareness of counternarratives, enables students to search for identification with others, and promotes their mutual transformation to understand one another." There is a clear invitation to learning to listen to each other rather than claiming that one (the researcher) is giving someone else a voice. Some disruptive methodological proposals in that sense include bricolage (Kincheloe, McLaren, \& Steimberg, 2011), communal reflection and reciprocal talk (Ortiz \& Arias, 2019), as well as the democratic approach (Haber, 2011).

\section{Moving Forward}

No matter how difficult the central theme of the research described here is, building together local knowledge in identity studies of gender diversity and sexual orientation, which connects with the teaching and learning of foreign languages and vice versa, is priceless. Arguably, that knowledge could go beyond research findings and beyond the communication of "scientific" knowledge. A practical side is needed to enable pedagogical action by revisiting pedagogies of foreign language teaching and pedagogies of initial and continuing education of language teachers. The critical and decolonial historicization of these language education programs in order to understand the discursive formations around gender diversity and sexual orientations is a pending task to be undertaken for a curricular transformation. In relation to curricular changes and transformations, Beemyn (2014, p. 111) states that "raising questions about how we understand gender-nonconforming people historically allows for a more nuanced analysis of the construction of gender and gender systems over time". In reality, we do not know clearly how modern categories coming from contemporary colonial gender perspectives were inserted into our profession. It is not a question of gender visibility. It is rather a matter of recognizing and welcoming subjectivities that are diverse.

From a language pedagogy perspective, we have been reflecting on ways of acting out educationally that are broad in their formulation and have no pretension of becoming an instructional dogma. In other words, we are not formulating the pedagogical perspective for teaching foreign languages within a gender perspective. We are sharing ideas in the hope of bringing language pedagogy itself out of the closet. These ideas or transformative practices could destabilize the possibility of a fixed pedagogical performance on the part of the language teacher or the language teacher educator. Mojica and Castañeda-Peña (2021) describe some of these transformative practices in relation to language teacher education.

\section{LGBTIQ+ Transformative Actions}

We insist that these transformation-oriented pedagogical practices are not simply formulas for descriptively developing the act of teaching and learning a foreign language. 
Rather, they are a pedagogical resignification of modern terms of gender diversity and sexual orientations stemming from modernity (e.g., LGBTIQ+). The purpose is to suggest pedagogical ways that otherwise welcome diversity in general and that, in one way or another, comprise an ethical attitude. This ethical attitude is a way to avoid the continuing epistemicide of gender and sexual orientations that contemporarily inhabit foreign language classrooms.

\section{Locating - Guaranteeing - Becoming - Transforming - Inviting - Questioning}

Locating issues of gender or sexual orientation in the discourses and representations circulating in classrooms can be difficult for some language teachers. However, appropriating this transformative practice could contribute to identifying potential moments of reflection and learning in the school context in general and by extension in the context of language teaching and learning.

Guaranteeing involves creating language learning environments that are healthy for teachers and students who possess non-conforming gender identities. This certainly implies language teachers becoming literate in relation to gender and sexual orientation diversity.

B ecoming gender literate. This means not only awareness but also education with respect to the various subjective manifestations of gender and sexual orientations. Therefore, initial and continuing education curricula for language teachers could include, not marginally but centrally, topics, reflections, and pedagogical activities around these diversity issues.

Transforming canonical understandings of gender and sexual orientation identities discursively and within the language curriculum. Permanent reflection plays a pivotal role in this transformative sense. In other words, we move from reflection to practical action.

Inviting guest speakers to offer the opportunity to share pedagogical experiences and reflections on gender diversity and sexual orientations. This transformative pedagogical practice is anchored in the experience of others which, as presented in this article, is growing in the local ELT community. A growing number of Colombian researchers are addressing the interface between gender and foreign language teaching/learning. Their research surely contributes in multiple and multifaceted ways to ELT gender identity and sexual orientation studies in the country. Furthermore, people who can contribute with their empirical experience or from other disciplines may be invited. This knowledge can add enormously to the education of pre-service and in-service teachers in our area of ELT. 
Questioning the curriculum in general and the types of content, communication contexts, and activities that are developed in language teacher education courses and language classes is perhaps one of the most pedagogically-relevant and transformative activities. In this sense, cultivating the critical and decolonial mind of teacher educators and pre-service and in-service teachers becomes important. Criticality could focus on understanding the subjectivities present in the classroom from a perspective of gender and sexual orientations that are subjugated by normalized practices of the exercise of power. Decoloniality is present in alert minds capable of distinguishing epistemological positionings related to gender and to the dispossession of diverse sex-gender identities.

Taking into consideration all these things allows us to establish that we are far from understanding many angles of the intersection between language learning and teaching and identity studies that focus on gender diversity and sexual orientations. This is where the "+" symbol of LGBTIQ makes sense, not from a perspective of addition but of intersectionality. This raises further questions that open up local research programs that can be integrated into a national and Latin American research agenda.

\section{References}

Beemyn, G. (2014). Transforming the curriculum: The inclusion of the experiences of trans people. In L. J. Rupp \& S. K. Freeman (Eds.), Understanding and teaching U.S. lesbian, gay, bisexual, and transgender history (pp. 111-122). The University of Wisconsin Press.

Berger, P., \& Luckman, Th. (2008). La construcción social de la realidad. Amorrortu.

Butler, J. (2004). Undoing gender. Routledge.

Butler, J. (2011). Bodies that matter: On the discursive limits of sex. Routledge.

Butler, J. (2015). Gender trouble. Feminism and the subversion of identity. Routledge.

Cameron, D. (2006). On language and sexual politics. Routledge.

Cameron, D., \& Kulick, D. (2006). The language and sexuality reader. Routledge.

Castañeda-Peña, H. (Ed.) (2021). Gender/Género \& ELT. Editorial Universidad Distrital Francisco José de Caldas.

Cheng, P. (2013). Espejo del Cristo queer asiático. Religión e Incidencia Pública. Revista de investigación cientifica de GEMRIP, 1, 1-33.

Coates, J. (2011). Language and gender: A reader. Willey-Blackwell.

Crenshaw, K. (1989). Demarginalizing the intersection of race and sex: A black feminist critique of antidiscrimination doctrine, feminist theory and antiracist politics. University of Chicago Legal Forum. Iss. 1, Article 8.

D’Emilio, J. (2002). The world turned: Essays on gay history, politics, and culture. Duke University Press. 
Eckert, P., \& McConnell-Ginet, S. (2013). Language and gender. Cambridge University Press. https:/ / doi.org/10.1017/CBO9781139245883

Foucault, M. (2002). Archeology of knowledge. Routledge.

Goffman, E. (1959). The presentation of self in everyday life. Penguin Psychology.

Grosfoguel, R. (2013). The structure of knowledge in westernized universities: Epistemic racism/ sexism and the four genocides/epistemicides of the long 16th century. Human Architecture: Journal of the Sociology of Self-Knowledge, Vol. 11, Article 8

Haber, A. (2011). Nometodología Payanesa: Notas de metodología indisciplinada. Revista de Antropología, 23(1), 9-49.

Hall, G. S. (1904). Adolescence: Its psychology and its relations to physiology, anthropology, sociology, sex, crime, religion and education. D. Appleton and Company.

Hall, S. (2011). Introduction: Who needs 'identity'? In S. Hall \& P. du Gay (Eds.), Questions of Cultural Identity (pp. 1-17). Sage.

Haraway, D. (1987). Manifesto for cyborgs: Science, technology, and socialist feminism in the 1980s. Socialist Review, 80, 65-108.

Kincheloe, J., McLaren, P., \& Steinberg, S. (2011). Critical pedagogy and qualitative research: Moving to the bricolage. In N. Denzin \& Y. Lincoln (Eds.), The SAGE Handbook of Qualitative Research 4 (pp. 163-177). Sage.

Lander, E. (Ed.) (2000). La colonialidad del saber: Eurocentrismo y ciencias sociales. Perspectivas latinoamericanas. Consejo Latinoamericano de Ciencias Sociales CLACSO.

Litosseliti, L. (2006). Gender and language: Theory and practice. Routledge.

Lugones, M. (2008). Colonialidad y Género. Tabula Rasa, 9, 73-101.

Maldonado-Torres, N. (2007). On the coloniality of being: contributions to the development of a concept. Cultural Studies, 21(2-3), 240-270.

Marcos, S. (2014). Feminismos en camino descolonial. In M. Millàn (Coord.), Más allá del feminismo: caminos por andar (pp. 15-34). Red de Feminismos Descoloniales.

Mendoza, B. (2016). Coloniality of gender and power: From postcoloniality to decoloniality. In L. Disch \& M. Hawkesworth (Eds.), The Oxford handbook of feminist theory (pp. 1-24). Oxford University Press.

Ortiz, A., \& Arias, M. (2019). Hacer decolonial: Desobedecer a la metodología de investigación. Hallazgos, 16(31), 149-161. https://doi.org/10.15332/s1794-3841.2019.0031.06

Pazargadi, L. M. (2019). Learning to listen: The power of transnational life storytelling. $a / b$ : Auto/ Biography Studies, 34(1), 141-145. https://doi.org/10.1080/08989575.2019.1542834

Preciado, B. (2008). Pharmaco-pornographic Politics: Towards a New Gender Ecology, Parallax, 14(1): 105-17.

Quijano, A. (2007). Colonialidad y clasificación social. In S. Castro-Gómez \& R. Grosfoguel (Eds.), El giro decolonial. Reflexiones para una diversidad epistémica más allá del capitalismo global (pp. 93-126). Siglo del Hombre Editores. 
Sabsay, L. (2012). The emergence of the other sexual citizen: Orientalism and the modernisation of sexuality. Citizenship Studies, 16(5-6), 605-623. https://doi.org/10.1080/13621025.2012.6 98484

Sabsay, L. (2016). The political imaginary of sexual freedom: Subjectivity and power in the new sexual democratic turn. Palgrave MacMillan.

Segato, R. L. (2010). Género y colonialidad: En busca de claves de lectura y de un vocabulario estratégico descolonial. In A. Quijano \& J. Navarrete (Eds.), La cuestión descolonial. Universidad Ricardo Palma - Cátedra América Latina y la Colonialidad del Poder. https://nigs.ufsc.br/ files/2012/09/genero_y_colonialidad_en_busca_de_claves_de_lectura_y_de_un_vocabulario_estrategico_descolonial_ritasegato.pdf

Shore-Goss, R. (2019). Derrocando a la heterosexualidad. Un Stonewall bíblico. Religión e Incidencia Pública. Revista de investigación científica de GEMRIP, 7, 91-117.

Sunderland, J. (1992). Gender in the EFL classroom. ELT Journal, 46(1), 81-91.

Sunderland, J. (1998). Girls being quiet: A problem for foreign language classrooms? Language Teaching Research, 2(1), 48-62.

Sunderland, J. (2000). New understandings of gender and language classroom research: Texts, teacher talk and student talk. Language Teaching Research, 4(2), 149-173.

Sunderland, J. (2004). Gendered discourses. Palgrave Macmillan.

Sunderland, J. (2006). Language and gender: An advanced resource book. Routledge.

Talbot, M. (2010). Language and gender. Polity.

Taylor, C. (1992). Sources of the self: The making of the modern identity. Harvard University Press.

Varga, B. A., Beck, T. A., \& Thornton, S. J. (2019). Celebrating Stonewall at 50: A culturally geographic approach to introducing LGBT themes. The Social Studies, 110(1), 33-42. https://doi. org/10.1080/00377996.2018.1536643

Walsh, C. (2007). Interculturalidad, colonialidad y educación. Revista Educación y Pedagogía, 19(48), 25-35.

\section{Annex 1}

Arias, C., \& Díaz, R. (2021). Narrative experiences of students in the L2 classroom related to heterosexist discursive practices. In H. Castañeda-Peña (Ed.), Género/Gender \& ELT (pp. 123-132). Editorial Universidad Distrital Francisco José de Caldas.

Ayala, S., \& Sánchez, J. (2010). Masculinidades Seme y Uke: Posicionamientos en el anime de tipo shonen-ai Gravitation (Seme and Uke masculinities: Positionings in the shonen-ai Gravitation-type mangas) [Unpublished B.Ed. paper in Languages]. Pontificia Universidad Javeriana.

Benavides-Buitrago, C. (2021). The gender discourse in the EFL classroom. In H. Castañeda-Peña (Ed.), Género/Gender \& ELT (pp. 191-196). Editorial Universidad Distrital Francisco José de Caldas. 
Bonilla, Y., \& Beltrán, J. (2010). Expresiones de los jóvenes homosexuales frente a la discriminación al interior de su circulo social (Opinions of young homosexuals about discrimination in their social circles) [Unpublished B.Ed. paper in Languages]. Pontificia Universidad Javeriana.

Castañeda-Peña, H., \& Soler, S. (1998). Los estudios de género sociolingüístico. Revista FOLIOS, 9(2), 20-27.

Castañeda-Peña, H. (2008a). Positioning masculinities and femininities in preschool EFL education. Signo y Pensamiento, 53(27), 314-326.

Castañeda-Peña, H. (2008b). I said it! I'm first! Gender and language-learner identities. Colombian Applied Linguistics Journal, 1(10), 112-125.

Castañeda-Peña, H. (2008c). Interwoven and competing gendered discourses in a preschool EFL lesson. In L. Litosseliti, H. Sauntson, K. Segall, \& J. Sunderland (Eds.), Theoretical and methodological approaches to gender and language study (pp. 256-268). Palgrave McMillan.

Castañeda-Peña, H. (2009a). “A game-specific approach to boyhood' - Book Review: Die tryin': videogames, masculinity, culture'. Signo y Pensamiento, 54(28), 384-385.

Castañeda-Peña, H. (2009b). Comunicación y Discurso: La perspectiva polifónica en los discursos literario, cotidiano y científico desde la agencia, la identidad y el género. Litterae, 13, 65-72.

Castañeda-Peña, H. (2009c). Masculinities and femininities go to preschool: Gender Positioning in discourse. Editorial Pontificia Universidad Javeriana.

Castañeda-Peña, H. (2010). 'The next teacher is going to be... Tereza Rico': Exploring gender positioning in an all-girl-preschool classroom. Magis, Revista Internacional de Investigación en Educación, 3(5), 107-124.

Castañeda-Peña, H. (2018). Structuralist, poststructuralist and decolonial identity research in English language teaching and learning: A reflection problematizing the field. In H. Castañeda-Peña et al., ELT Local Research Agendas I (pp. 17-34). Editorial Universidad Distrital Francisco José de Caldas.

Castañeda-Peña, H. (2019). Gender and LTE. In G. Barkhuizen (Ed.), Qualitative research topics in language teacher education (pp. 126-130). Routledge.

Castañeda-Peña, H., \& Mojica, C. (2017). Formación de docentes de lenguas extranjeras: Una perspectiva crítica y generizada en un caso colombiano. In J. D. Marcelo de., F. Zolin-Vesz, \& D. Carbonieri (Eds.), Perspectivas críticas no ensino de linguas: Novos sentidos para a Escola (pp. 77-88). Ponte Editores.

Castañeda-Londoño, A. (2012). EFL women-learners construction of the discourse of egalitarism and knowledge in online-talk-in-interaction. Colombian Applied Linguistics Journal, 14(1), 163 179.

Camacho, C. (2021). Genderlects in teaching and learning EFL. In H. Castañeda-Peña (Ed.), Género/Gender \& ELT (pp. 69-76). Editorial Universidad Distrital Francisco José de Caldas.

Chaparro, J. (2021). Emerging reflective discourses on gender in an EFL class. In H. Castañeda-Peña (Ed.), Género/Gender \& ELT (pp. 205-214). Editorial Universidad Distrital Francisco José de Caldas. 
Delgado-Ochoa, J. (2021). Challenging hegemonic discourses of gender: Emergence of the third space. In H. Castañeda-Peña (Ed.), Género/Gender \& ELT (pp. 225-232). Editorial Universidad Distrital Francisco José de Caldas.

Durango, J., \& Moyano, M. (2016). Discursos heteronormativos y no heteronormativos en aulas de L2 en colegios de Bogotá (Heteronormative and non-heteronormative discourses in L2 classrooms in Bogotá) [Unpublished B.Ed. paper in Languages work]. Pontificia Universidad Javeriana.

Escobar, M. (2021). Gender and sexual identities in EFL in Colombia: Narratives of L2 experiences of gay and lesbian students at a private university. In H. Castañeda-Peña (Ed.), Género/ Gender \& ELT (pp. 87-96). Editorial Universidad Distrital Francisco José de Caldas.

Farfán, A. (2021). Violent discourses and the (co)construction of gendered identities in an EFL classroom. In H. Castañeda-Peña (Ed.), Género/Gender \& ELT (pp. 141-148). Editorial Universidad Distrital Francisco José de Caldas.

Forero, M., \& Castañeda, F. (2012). Los colores del arcoiris van juntos pero no se mezclan (The colors of the rainbow go together but they do not blend). Ethnographic study of the discursive practices of homophobic endodiscrimination in ambits like the gay bars and discos in the district of Chapinero [Unpublished B.Ed. paper in Languages]. Pontificia Universidad Javeriana.

Galeano, P., \& Sánchez, J. (2021). The narratives of queer students in content-based foreign language classes. In H. Castañeda-Peña (Ed.), Género/Gender \& ELT (pp. 105-112). Editorial Universidad Distrital Francisco José de Caldas.

Granados-Beltrán, C. (2021). Attempting to decolonize gender in a B.A. ELT program. In H. Castañeda-Peña (Ed.), Género/Gender \& ELT (pp. 269-276). Editorial Universidad Distrital Francisco José de Caldas.

Herrera, D. (2021). ELT materials and children's rights: Gender, agency and citizenship education. In H. Castañeda-Peña (Ed.), Género/Gender \& ELT (pp. 175-182). Editorial Universidad Distrital Francisco José de Caldas.

Malagón, L. (2021). Teachers' gender beliefs and teaching practices in single-sex EFL classrooms. In H. Castañeda-Peña (Ed.), Género/Gender \& ELT (pp. 159-166). Editorial Universidad Distrital Francisco José de Caldas.

Mojica, C. (2021). The professional development of EFL teachers: How to incorporate a gender perspective into the practices of Colombian teachers. In H. Castañeda-Peña (Ed.), Género/ Gender \& ELT (pp. 247-258). Editorial Universidad Distrital Francisco José de Caldas.

Mojica, C., \& Castañeda-Peña, H. (2017). A learning experience of the gender perspective in English teaching contexts. Profile: Issues in Teachers' Professional Development, 19(1), 139-153. http:/ / dx.doi.org/10.15446/profile.v19n1.56209

Mojica, C., \& Castañeda-Peña, H. (2021). Helping English language teachers become gender aware. ELT Journal, 75(2), 203-212. https://doi.org/10.1093/elt/ccaa076

Moreno, L. (2011). Mientras los hombres trabajan las mujeres planchan (While the men work, the women iron) $A$ discursive analysis of a textbook for boys and girls. Windows 6 [Unpublished B.Ed. paper in Languages] Pontificia Universidad Javeriana. 
Munevar, P. (2009). ¿Te vas a tirar? Study of the campaign to promote the use of condoms (condon pilo): An analysis of the discourse [Unpublished B.Ed. paper in Languages]. Pontificia Universidad Javeriana.

Muñoz, L. (2016). Gender inequality in oral participation: Exploring eighth graders' discourses in an EFL classroom [Unpublished M.A. thesis in TEFL]. Universidad Distrital Francisco José de Caldas.

Ospina, N. (2011). Estudio descriptivo del lenguaje empleado por parte de los estudiantes de la Facultad de Comunicación y Lenguaje de la Pontificia Universidad Javeriana para referirse a los hombres homosexuales (Descriptive study of the language used by students in the Faculty of Communication and Language at the Javeriana University to describe homosexual men) [Unpublished B.Ed. paper in Languages]. Pontificia Universidad Javeriana.

Rodríguez, A. (2018). English language teachers'pedagogical practices in relation with their gendered identities construction (Prácticas pedagógicas de profesores de inglés en relación con la construcción de sus identitades generizadas) [Unpublished B.Ed. paper in Languages]. Universidad Pedagógica y Tecnológica de Colombia.

Rojas, M. (2012). Female EFL teachers: Shifting and multiple gender and language-learner identities. Colombian Applied Linguistics Journal, 14(1), 92-107.

Rondón, F. (2012). LGBT students' short-range narratives and gender performance in the EFL classroom. Colombian Applied Linguistics Journal, 14(1), 77-91.

Salazar, N., \& García, K. (2014). Narrativa autobiográfica de un profesor de inglés abiertamente homosexual (Autobiographical narrative of an openly homosexual English teacher) [Unpublished B.Ed. paper in Languages]. Pontificia Universidad Javeriana.

Tenorio, L. (2015). Razones potenciales tras la omisión de representación de género (LGTBI) en los materiales didácticos utilizado en las clases de inglés intermedio de la LLM de la PUJ (Potential reasons for the omission of LGTB gender representations in the didactic materials used in intermediate-level English classes from the B.Ed. in Modern Languages at Pontificia Universidad Javeriana) [Unpublished B.Ed. paper in Languages]. Pontificia Universidad Javeriana.

Ubaque-Casallas, D., \& Castañeda-Peña, H. (2020). Non-normative corporalities: Transgender/blind identity in an English as a foreign language student teacher. $H O W, 27(2), 13-30$. https://doi.org/10.19183/how.27.2.548

Ubaque-Casallas, D., \& Castañeda-Peña, H. (2021). "I'm here and I am queer." Queer teacher identities in ELT. A Colombian study. Revista FOLIOS, 53, 91-106. https://doi.org/10.17227/ folios.53-11291 